\title{
ANALISA RISIKO DAN KEUNTUNGAN INVESTASI SAHAM BATU BARA DI BURSA EFEK INDONESIA (Tahun 2010-2014)
}

\author{
Oleh: \\ Siti Nur Zahroh \\ Fakultas Ekonomi Universitas Muhammadiyah Malang \\ E-mail: sn_zahrah@yahoo.co.id
}

\begin{abstract}
This research was motivated by the increasing value of the production and consumption of coal from year to year, but is not offset by an increase in new investment in this sector. Each selection of investment decisions certainly linked to the degree of risk and benefit ratio, in order to know how much future investment results that will be obtained with the level of risk to a minimum. The purpose of this study was to measure the level of risk and benefit ratio of shares in a coal mining company listed on the Stock Exchange during the study period 2010-2014. Calculation of the level of risk in this study was measured by VaR (Value at Risk) and the profit rate is measured with RAROC (Risk Adjusted Return on Capital). The results of this study indicate that the coal mining stocks are a potential value loss (high risk low return). The highest VaR value during the study period experienced by PKPK of 0.64300 or $64.30 \%$ in 2010 . The market value of the highest RAROC during the observation period by ITMG in 2010 amounted to 0.4304 or $43 \%$.
\end{abstract}

Keywords: Risk, Gain, VaR (Value at Risk), RAROC (Risk Adjusted Return on Capital), Shares, Indonesia Stock Exchange.

\begin{abstract}
ABSTRAK
Penelitian ini dilatar belakangi oleh semakin meningkatnya nilai produksi dan konsumsi batu bara dari tahun ke tahun, namun tidak di imbangi dengan peningkatan investasi baru disektor ini. Setiap pilihan keputusan investasi pasti dihubungkan dengan tingkat risiko dan tingkat keuntungan, dengan demikian dapat diketahui seberapa besar nantinya hasil investasi yang akan diperoleh dengan tingkat risiko yang seminimal mungkin. Tujuan penelitian ini adalah untuk mengukur tingkat risiko dan tingkat keuntungan saham pada perusahaan pertambangan batu bara yang tercatat di BEI selama periode penelitian tahun 2010-2014. Perhitungan tingkat risiko dalam penelitian ini diukur dengan VaR(Value at Risk) dan tingkat keuntungan diukur dengan RAROC(Risk Adjusted Return On Capital). Hasil dari penelitian ini menunjukkan bahwa pada saham pertambangan batu bara terdapat nilai potensi kerugian (high risk low return). Nilai VaR tertinggi selama periode penelitian dialami oleh PKPK sebesar 0.64300 atau $64.30 \%$ pada tahun 2010. Sedangkan untuk nilai RAROC tertinggi selama periode pengamatan oleh ITMG pada tahun 2010 sebesar 0.4304 atau $43 \%$.
\end{abstract}

Kata Kunci: Risiko, Keuntungan, VaR (Value at Risk), RAROC (Risk Adjusted Return on Capital), Saham, Bursa Efek Indonesia. 


\section{PENDAHULUAN}

Sebagai negara berkembang yang terus melakukan pembangunan di segala bidang, Indonesia memerlukan sumber energi untuk menggerakkan pembangunannya. Sumber energi yang dapat digunakan dapat dibagi menjadi dua, yaitu: sumber energi yang dapat diperbaharui (renewable energy resources), dan sumber energi yang tidak dapat diperbaharui (non renewable energy resources). Selain minyak bumi, batu bara adalah sumber energi tidak terbaharui yang memegang peran dominan, yaitu sebagai sumber pembangkit energi pada PLTU batu bara.

Menurut Suryana (2011), kebutuhan batu bara sebagai sumber energi sejalan dengan laju pertumbuhan ekonomi dan pembangunan. Hal ini tidak hanya terjadi untuk negara berkembang atau Indonesia semata, akan tetapi juga untuk kebutuhan di dunia. Jika ingin melakukan pembangunan yang pesat maka dibutuhkan listrik sebagai energi, dan ini juga berarti diperlukan batu bara yang melimpah sebagai sumber energi. Berkaitan dengan semakin meningkatnya kebutuhan dunia terhadap energi termasuk batu bara, efisiensi penggunaan batu bara perlu dilakukan. Hal ini tidak terlepas dari keberadaan batu bara sebagai non renewable energy resources. Dalam perkembangan ke depannya, Pemerintah RI melalui Departemen ESDM telah menyusun roadmap energi nasional. Dalam hal ini, batu bara memegang peranan sangat penting untuk menggantikan posisi minyak bumi yang cadangannya mulai menipis.

Produksi batu bara Indonesia cenderung meningkat dari tahun ke tahun. Namun peningkatan produksi batu bara Indonesia ternyata tidak serta merta diikuti dengan meningkatnya investasi baru di sektor ini. Sebagaimana diketahui, investasi merupakan salah satu indikator pertumbuhan perekonomian nasional.

Samsul (2006:146) menjelaskan, investasi pada hakikatnya merupakan penempatan sejumlah dana pada saat ini dengan harapan untuk memperoleh keuntungan dimasa yang akan datang. 
Ada dua faktor yang dipertimbangkan dalam pengambilan keputusan, yaitu tingkat pengembalian dan risiko. Investasi di pasar modal sangat memerlukan pengetahuan yang cukup, pengalaman, serta naluri bisnis untuk menganalisis efek-efek mana saja yang akan dibeli, mana yang akan dijual dan mana yang akan tetap dimiliki. Sedangankan menurut Yohatin (2009), tingkat keuntungan yang diperoleh di pasar modal dalam bentuk surat berharga khususnya saham lebih besar dibandingkan tingkat keuntungan di pasar uang yang ditanamkan dalam bentuk deposito.

Husnan (2001:3) mengatakan, pertumbuhan perekonomian suatu negara dapat diukur dengan berbagai cara, salah satunya adalah dengan mengetahui tingkat perkembangan dunia pasar modal dan industriindustri sekuritas yang ada pada negara tersebut. Pasar modal didefinisikan sebagai pasar untuk berbagai instrument keuangan (sekuritas) jangka panjang yang bisa diperjual belikan, baik dalam bentuk hutang ataupun modal sendiri, baik yang diterbitkan pemerintah, public authorizes, maupun perusahaan swasta.

Darmadji dan Fakhrudin (2001:10) menjelaskan, pada dasarnya pasar modal juga dikenal dengan karakteristik high risk - high return. Artinya penanaman saham pasar modal memberikan peluang keuntungan tinggi namun juga berpotensi risiko tinggi. Pasar modal juga memungkinkan investor untuk mendapatkan return atau keuntungan (capital gain) dalam jumlah besar dalam waktu singkat. Namun, seiring dengan harga yang fluktuatif, maka dapat membuat investor mengalami kerugian atau risk besar dalam waktu yang singkat pula.

Jadi dalam melakukan investasi hal yang perlu diperhatikan adalah keuntungan dan risiko dari investasi tersebut. Menurut Muslih (2008), dalam berinvestasi pada pasar modal, ada dua hal yang akan dihadapi oleh investor, yaitu tingkat keuntungan yang diharapkan dan tingkat risiko. Unsur risiko selalu melekat dalam dunia investasi. Dengan adanya risiko ini, investor akan mengalami atau menerima keuntungan yang tidak sesuai harapan sehingga 
mengakibatkan timbulnya

a. Menghitung Keuntungan, penyimpangan-penyimpangan yang sering disebut ketidakpastian (uncertainty). Dari uraian diatas, maka peneliti tertarik meneliti permasalahan yang terjadi dengan judul "analisa risiko dan keuntungan investasi saham batu bara di bursa efek indonesia (tahun 2010-2014)".

\section{METODE PENELITIAN}

Penelitian ini termasuk penelitian deskriptif dengan pendekatan kuantitatif. Data yang digunakan adalah data sekunder. Teknik pengumpulan data dalam penelitian ini yaitu menggunakan teknik dokumentasi.

Populasi yang digunakan dalam penelitian ini adalah seluruh perusahaan pertambangan batu bara (coal mining) yang tercatat di Bursa Efek Indonesia (BEI) selama periode pengamatan 2010 sampai 2014 sebanyak 22 perusahaan. Dalam pengumpulan sampel penelitian ini menggunakan metode purposive sampling.

Teknik analisis data yang digunakan dalam penelitian ini adalah sebagai berikut;

Expected Return dan Risiko

Return atau tingkat keuntungan perusahaan menjadi salah satu indikator yang menentukan seorang investor dalam menginvestasikan dananya ke perusahaan. Return dapat diartikan sebagai tingkat keuntungan yang diperoleh atau diharapkan dari suatu investasi dalam periode waktu tertentu yang akan diperoleh dimasa yang akan datang. Return realisasi: (Fakhruddin dan Hadianto, 2001:31)

$$
R_{t}=\frac{P_{t}-P_{t-1}}{P_{t-1}}
$$

Dimana:

$\mathrm{Rt}=$ return pada hari ke $t$

$\mathrm{Pt}=$ closing price pada hari ke $t$

Pt-1=closing price pada hari ket-1

Expected return merupakan tingkat keuntungan yang diharapkan akan diperoleh oleh investor di masa mendatang. Expected return dapat diestimasi dengan rumus berikut: Rumus expected return: (Jogiyanto, 2000:126)

$$
E\left(R_{i}\right)=\sum_{j=1}^{n}\left(R_{j} \cdot p_{j}\right)
$$

Dimana : 
$\mathrm{E}(\mathrm{Ri})=$ return ekspektasi suatu aktifa atau sekuritas ke-i

$\mathrm{Rj}=$ hasil masa depan ke $\mathrm{j}$

$\mathrm{Pj}=$ probabilitas masa depan $\mathrm{ke} \mathrm{j}$

$\mathrm{n}=$ jumlah dari hasil masa depan

Risiko merupakan kemungkinan perbedaan antara return realisasi yang diterima dengan expected return. Ukuran risiko dapat dilihat dengan standar deviasi. Rumus standar deviasi: (Fakhruddin dan Hadianto, 2001:27)

$$
S D=\sqrt{\frac{\sum_{i=1}^{n}\left(X_{i}-\bar{X}\right)^{2}}{n-1}}
$$

Dimana:

$\mathrm{SD}=$ standar deviasi

$\mathrm{Xi}=$ nilai $k e-i$

$\mathrm{X}=$ nilai rata-rata

$\mathrm{n}=$ jumlah observasi

b. Menentukan Nilai VaR

Menurut Philip Best (1998, dalam Hidayati 2006) Value at Risk atau VaR adalah suatu metode pengukuran risiko secara statistik yang memperkirakan kerugian maksimum yang mungkin terjadi atas suatu portfolio pada tingkat kepercayaan (level of confidence) tertentu. Nilai VaR selalu disertai dengan probabilitas yang menunjukkan seberapa mungkin kerugian yang terjadi akan lebih kecil dari nilai VaR tersebut. VaR adalah suatu nilai kerugian moneter yang mungkin dialami dalam jangka waktu yang telah ditentukan.

Menurut Tahir (2012), metode pengukuran bobot bersih risiko dengan pendekatan $\mathrm{VaR}$ dapat dijelaskan sebagai berikut:

a) Metode pengukuran risiko dihitung dengan estimasi persentase kerugian potensial melalui VaR nilai absolut dan nilai relatif. Nilai VaR absolut adalah kerugian terhadap zero (nol) dan nilai VaR relatif adalah kerugian yang dibandingkan dengan rata-rata nilai pengembalian hasil yang diharapkan (expected return) $\mu$. Estimasi pendekatan VaR dapat dilihat dengan formulasi sebagai berikut:

$\operatorname{VaR}($ mean $)=\mathrm{A} 0 \alpha \sigma \sqrt{T}$

$\operatorname{VaR}($ zero $)=\mathrm{A} 0(\alpha \sigma \sqrt{T}-\mu \mathrm{T})$

Dimana A0 menunjukkan nilai yang dinvestasika pada 
tingkat pengembalian hasil

(rate of return), $\alpha$ menunjukkan distribusi standar normal, $\sigma$ menunjukkan standar deviasi, $\mathrm{T}$ menunjukkan selang waktu dimana ditentukan dalam tahun, (sehingga dalam satu bulan menjadi 1/12) dan $\mu$ menunjukkan tingkat pengembalian hasil yang diharapkan (expected return).

b) VaR absolute dan VaR relative menggunakan metode parametric yang dikalikan dengan dua parameter quantitatif yaitu tingkat kepercayaan (confidence level) dan horizon waktu disebabkan sifat pengukurannya adalah estimasi. Tingkat kepercayaan didasarkan pada nilai distribusi standar normal $(\alpha)$ yang dapat dicari dari tabel kurva normal sebesar 1.65 untuk tingkat kepercayaan $c$ 95\% dan 2.33 untuk tingkat kepercayaan $99 \%$.

c. Menentukan Nilai RAROC

Menurut Prokopczuk dan Trauck (2004:3-6), RAROC dikembangkan oleh Banker Trust pada akhir 1970-an, yang bertujuan untuk mengukur risiko dengan mempertimbangkan tradeoff antara risiko dan pendapatan dari berbagai aset dan aktivitas yang berbeda. Sebelumnya Banker Trust menyebutnya dengan istilah RAPMs (Risk Adjusted Performance Measures), dan menjadi popular dalam bisnis perbankan pada waktu itu. Banyak singkatan RAPMs yang dapat ditemukan dalam literatur, misalnya RAR, ROC, RAROC, RORAC, RARORC, RAROEC, RARORAC. Ini bisa sangat membingungkan, terutama karena singkatan yang sama bisa bararti berbeda dan hal yang sama kadang-kadang memiliki singkatan yang bebeda pula. Sehingga pada akhir tahun 1970an Bankers Trust menyebutnya sebagai RAROC (Risk Adjusted Return on Capital).

Jika kita mengekspresikan Model Ekonomi sebagai VaR, menjadi:

$$
\text { RAROC }=\frac{\text { Expected Return }}{\operatorname{VaR}}
$$

PEMBAHASAN 
Pasar modal Indonesia secara historis telah hadir jauh sebelum Indonesia merdeka. Pasar modal atau bursa efek telah hadir sejak jaman kolonial Belanda, tepatnya pada tahun 1912 di Batavia. Pasar modal ketika itu didirikan oleh pemerintah Hindia Belanda untuk kepentingan pemerintah kolonial atau VOC. Instrument keuangan yang diperdagangakan di pasar modal merupakan instrument jangka panjang, baik surat utang (obligasi), ekuiti (saham), reksa dana, instrument derivative maupun instrument lainnya. (www.idx.co.id)

Di Indonesia, pasar modal atau bursa efek di atur dan di awasi oleh OJK (Otoritas Jasa Keuangan). UU Nomor 21 Tahun 2011 menyebut, lembaga-lembaga yang akan berada di bawah pengawasan OJK adalah perbankan, pasar modal, perasuransian, dana pensiun, lembaga pembiayaan atau multifinance, dan lembaga jasa keuangan lainnya. OJK mempunyai tugas melakukan pengaturan dan pengawasan terhadap kegiatan jasa keuangan di sektor perbankan, sektor pasar modal, dan sektor IKNB. Sehingga diharapkan agar keseluruhan kegiatan di dalam sektor jasa keuangan dapat terselenggara secara teratur, adil, transparan, dan akuntabel. Yang mampu mewujudkan sistem keuangan yang tumbuh secara berkelanjutan, stabil dan mampu melindungi kepentingan konsumen dan masyarakat. (www.ojk.go.id)

Perusahaan pertambangan masuk dalam sektor utama, perusahaanperusahaan yang masuk sektor utama merupakan perusahaan-perusahaan penghasil bahan baku. Dalam penelitian ini data yang diperlukan yaitu data perusahaan yang masuk dalam sub sektor pertambangan batu bara (coal mining). Tercatat ada 22 perusahaan pertambangan di Indonesia yang merupakan perusahaan publik (tercatat di BEI) yang masuk kategori perusahaan industri penghasil bahan baku sektor pertambangan, sub sektor pertambangan batu bara selama periode penelitian 2010-2014. Namun hanya terdapat 6 perusahaan yang memenuhi kriteria untuk dijadikan sampel penelitian. Daftar dari perusahaan-perusahaan tersebut dapat dilihat pada tabel berikut ini: 
Tabel 1. Daftar Perusahaan Pertambangan Batu bara

\begin{tabular}{ccl} 
No. & Kode & Emiten \\
\hline 1 & ADRO & Adaro Energy Tbk \\
2 & ATPK & ATPK Resources Tbk \\
3 & BUMI & Bumi Resources Tbk \\
4 & ITMG & Indo Tambang Megah Tbk \\
5 & PKPK & Perdana Karya Perkasa Tbk \\
6 & PTBA & Bukit Asam Tbk \\
\hline
\end{tabular}

Sumber: Data yang diolah, 2015

1. Hasil Analisis Keuntungan, Expected Return dan Risiko

Tabel 2. Expected Return Perusahaan Pertambangan Batu Bara

\begin{tabular}{lccccc} 
Emiten & \multicolumn{5}{c}{ Expected Return } \\
\cline { 2 - 6 } & 2010 & 2011 & 2012 & 2013 & 2014 \\
\hline ADRO & 0.030 & -0.014 & -0.008 & -0.025 & 0.012 \\
\hline ATPK & 0.019 & -0.007 & 0.010 & 0.085 & -0.027 \\
\hline BUMI & 0.026 & -0.011 & -0.117 & -0.059 & -0.103 \\
\hline ITMG & 0.047 & -0.012 & 0.015 & -0.024 & -0.045 \\
\hline PKPK & -0.043 & 0.020 & 0.073 & -0.061 & 0.013 \\
\hline PTBA & 0.030 & -0.009 & -0.022 & -0.029 & 0.029 \\
\hline
\end{tabular}

Sumber: Data yang diolah, 2015

Tabel 3. Risiko Perusahaan Pertambangan Batu Bara

\begin{tabular}{cccccc}
\hline Emiten & \multicolumn{5}{c}{ Risiko } \\
\cline { 2 - 6 } & 2010 & 2011 & 2012 & 2013 & 2014 \\
\hline ADRO & 0.067 & 0.118 & 0.097 & 0.155 & 0.083 \\
\hline ATPK & 0.220 & 0.071 & 0.306 & 0.125 & 0.048 \\
\hline BUMI & 0.127 & 0.131 & 0.114 & 0.150 & 0.145 \\
\hline ITMG & 0.066 & 0.089 & 0.089 & 0.143 & 0.095 \\
\hline PKPK & 0.150 & 0.081 & 0.390 & 0.153 & 0.151 \\
\hline PTBA & 0.091 & 0.066 & 0.090 & 0.129 & 0.056 \\
& & & & &
\end{tabular}


Sumber: Data yang diolah, 2015

Dari penjelasan masing-masing keuntungan dan risiko saham diatas dapat disimpulkan bahwa nilai keuntungan saham pertambangan batu bara mengalami fluktuasi, sehingga calon investor harus siap akan adanya keuntungan atau bahkan kerugian yang akan diterima nantinya.

2. Hasil Analisis VaR

Perbandingan nilai VaR (mean) sebagai berikut:

Tabel 4. Perbandingan VaR Emiten Batu Bara

\begin{tabular}{cccccc}
\hline Emiten & \multicolumn{5}{c}{ Value at Risk } \\
\cline { 2 - 6 } & 2010 & 2011 & 2012 & 2013 & 2014 \\
\hline ADRO & 0.110 & 0.195 & 0.160 & 0.257 & 0.137 \\
\hline ATPK & 0.364 & 0.116 & 0.505 & 0.206 & 0.079 \\
\hline BUMI & 0.209 & 0.217 & 0.188 & 0.247 & 0.239 \\
\hline ITMG & 0.108 & 0.147 & 0.146 & 0.236 & 0.156 \\
\hline PKPK & 0.247 & 0.134 & 0.643 & 0.252 & 0.250 \\
\hline PTBA & 0.150 & 0.109 & 0.149 & 0.213 & 0.093
\end{tabular}

Sumber: Data yang diolah, 2015

Dari tabel perbandingan yang disajikan penulis terkait dengan data nilai VaR (mean) yang menjadi faktor risiko yang dapat mengurangi pendapatan investasi pada saham pertambangan batu bara, kita dapat mengetahui bahwa pada tahun 2010 VaR (mean) terbaik dimiliki ITMG sebesar 0.10835 dan nilai terburuk dimiliki ATPK sebesar 0.36356 . Sedangkan pada tahun 2011 nilai VaR terbaik oleh PTBA 0.10902 dan nilai terburuk dimiliki BUMI sebesar 0.21690. Pada tahun 2012 nilai VaR terbaik dimiliki ITMG sebesar 0.14610 dan nilai terburuk oleh PKPK sebesar 0.64300. Untuk tahun 2013 nilai VaR terbaik oleh ATPK sebesar 0.20586 dan nilai terburuk oleh ADRO sebesar 0.25653, dan untuk tahun 2014 diketahui nilai VaR terbaik dimiliki oleh ATPK sebesar 0.07865 sedangkan nilai terburuk oleh PKPK sebesar 0.24980 .

3. Hasil analisis RAROC

Perbandingan nilai RAROC sebagai berikut:

Tabel 5. Perbandingan RAROC Emiten Batu Bara

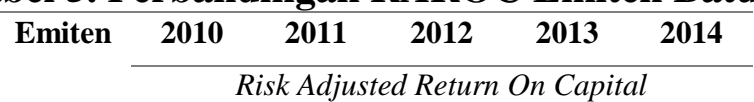




\begin{tabular}{cccccc}
\hline ADRO & 0.271 & -0.073 & -0.050 & -0.099 & 0.084 \\
\hline ATPK & 0.053 & -0.058 & 0.020 & 0.413 & -0.339 \\
\hline BUMI & 0.124 & -0.052 & -0.622 & -0.239 & -0.431 \\
\hline ITMG & 0.430 & -0.083 & 0.104 & -0.101 & -0.286 \\
\hline PKPK & -0.175 & 0.152 & 0.114 & -0.242 & 0.052 \\
\hline PTBA & 0.204 & -0.087 & -0.146 & -0.134 & 0.315 \\
\hline
\end{tabular}

Sumber: Data yang diolah, 2015

Dari tabel perbandingan risiko investasi pada saham perusahaan batu bara terkait nilai pertambangan batu bara setelah RAROC yang dimiliki maka ITMG memiliki nilai RAROC terbesar pada tahun 2010 yaitu sebesar 0.4304 dan nilai terkecil dimiliki oleh PKPK 0.17458. Pada tahun 2011 nilai RAROC tertinggi oleh saham PKPK sebesar 0.15195 dan nilai terendah oleh PTBA sebesar -0.0869 . Sedangkan untuk nilai RAROC terbaik tahun 2012 dimiliki PKPK sebesar 0.11392 dan nilai terendah oleh BUMI sebesar -0.62202. Untuk tahun 2013 nilai RAROC terbaik dimiliki ATPK sebesar 0.4132 sedangkan untuk nilai terendah tahun 2013 dimiliki oleh PKPK sebesar 0.24196 dan untuk nilai RAROC terbaik tahun 2014 oleh PTBA dengan nominal 0.315 sedangakn nilai terburuk dengan nominal 0.43059 oleh BUMI.

\section{PENUTUP}

Berdasarkan penjelasan yang telah dikemukakan di atas mengenai diukur dengan dengan pendekatan VaR dan tingkat keuntungan saham pertambangan batu bara setelah diukur dengan pendekatan RAROC dapat diambil kesimpulan sebagai berikut:

Investasi saham pertambangan batu bara cenderung mengalami potensi kerugian dikarenakan $\mathrm{VaR}$ (zero) menunjukkan nilai positif, atau dengan kata lain investasi saham pertambangan batu bara menyatakan bahwa hubungan antara VaR (zero) dengan rata-rata gross expected return tidak terdapat nilai prospektif artinya high risk low return.

Investor dapat memahami bahwa bobot net return investasi saham pertambangan batu bara diperoleh antara selisih nilai gross expected return dengan VaR (mean). Sebagaimana dapat digambarkan pada lampiran 4, pada saham ADRO tahun 2010 nilai rata-rata gross expected return sebesar -97.02 
persen dan VaR (mean) sebesar 10.97 persen, maka net return yang dihasilkan adalah -108.00 persen. Artinya tidak terdapat keuntungan atau tidak adanya nilai pendapatan yang akan diperoleh investor. Penjelasan yang sama juga berlaku untuk keenam saham lainnya.

Dari hasil perhitungan didapatkan nilai VaR tertinggi atau dengan kata lain emiten dengan nilai kerugian maksimum tertinggi pada tahun 2010 adalah ATPK sebesar 0.36356 atau $36.36 \%$. pada tahun 2011 nilai VaR tertinggi oleh BUMI sebesar 0.21690 atau $21.69 \%$, dan untuk tahun 2012 nilai VaR tertinggi dimiliki PKPK sebesar 0.64300 atau $64.30 \%$. Sedangkan untuk tahun 2013 dan 2014 nilai VaR tertinggi adalah ADRO dan PKPK masingmasing sebesar 0.25653 atau $25.65 \%$ dan 0.24980 atau $24.98 \%$. Nilai VaR tertinggi selama periode penelitian dialami oleh PKPK sebesar 0.64300 atau $64.30 \%$.

Analisis RAROC menunjukkan bahwa bobot bersih keuntungan (return) yang telah dipertimbangkan oleh risiko dan return mengalami fluktuasi nilai selama periode observasi 2010-2014.

$\begin{array}{ccr}\text { Bobot } & \text { bersih } & \text { keuntungan } \\ \text { terhadap } & \text { RAROC } & \text { investasi }\end{array}$
perusahaan pertambangan batu bara menunjukkan bahwa total keuntungan yang telah disesuaikan dengan besarnya risiko lebih kecil dari rata-rata kerugian. Hal ini berarti perusahaan pertambangan batu bara mencerminkan adanya kerugian yang tinggi terhadap pemanfaatan dan produktivitas usaha investasi.

Berdasarkan hasil perhitungan RAROC diketahui bahwa nilai keuntungan tertinggi tahun 2010 oleh ITMG sebesar 0.4304 atau $43 \%$, dan untuk tahun 2011 oleh PKPK sebesar 0.1520 atau $15 \%$. Nilai RAROC tertinggi pada tahun 2012 dimiliki PKPK sebesar 0.1139 atau $11 \%$, dan sebesar 0.4132 atau $41 \%$ oleh ATPK pada tahun 2013. Sedangkan RAROC tertinggi tahun 2014 oleh PTBA sebesar 0.3150 atau $32 \%$. Untuk niali RAROC tertinggi selama periode pengamatan oleh ITMG pada tahun 2010 sebesar 0.4304 atau $43 \%$.

\section{DAFTAR PUSTAKA}

Adinugroho, Kristanto. 2001. Analisis Perbandingan Risiko Sistematik dan Tingkat Keuntungan pada Saham di 
Industri Perbankan dan

IDX.

2015.

Sejarah,

Industri Properti.

Darmadji, Tjiptono dan Fakhruddin, Hendy M. 2001. Pasar Modal di Indonesia: Pendekatan

Tanya Jawab, Salemba

Empat, Jakarta.

Fakhruddin M, Hadianto Sopian M. 2001. Perangkat dan Model Analisis Investasi Di Pasar

Modal, PT Elex Media Komputindo Kelompok

Gramedia, Jakarta.

Halim, Abdul. 2003. Analisis Investasi, Salemba Empat, Jakarta.

Hidayati, Lina Nur. 2006. Mengukur Risiko Perbankan Dengan VaR (Value at Risk).

Husnan, Suad. 2001. Dasar-Dasar Teori Portofolio dan Analisis Sekuritas, Edisi Ketiga, UPP AMP YKN, Yogyakarta.

IDX. 2015. Pengantar Pasar Modal, http://www.idx.co.id/id$\mathrm{id} /$ beranda/informasi/bagiinv estor/pengantarpasarmodal.as px , diakses 19 Januari 2015.

Muslih, M. Imam. 2008. Perbandingan Model CAMP Dengan APT dalam Memprediksi Imbalan Saham Industri Pertambangan di Bursa Efek Indonesia.

OJK. 2015. Tugas dan Fungsi, http://www.ojk.go.id/tugasdan-fungsi, diakses 19 Januari 2015.

Prokopczuk, M, S Rachev and S Truck. 2004. Quantifying Risk In The Electricity Business: A RAROC - Based Approach.

Samsul, Mohamad. 2006. Pasar Modal dan Manajemen Portofolio, Erlangga, Jakarta.

Sitompul, Asril. 2000. Pasar Modal: Penawaran Umum dan Permasalahannya, PT. Citra Aditya Bakti, Bandung. 
Sjahrir. 1993. Analisis Pasar Modal, Pustaka Sinar Haarapan, Jakarta.

Suryana, I Made Edy. 2011. Kaitan

Produksi Batu bara dengan

Investasi dan Penyerapan

Tenaga Kerja, Warta

Minerba, Edisi XI:22. www.minerba.esdm.go.id, 3

Februari 2015.

Tahir, Faizal Rakhmat. 2012. Analisis Perhitungan Risiko dan Pendapatan dari Sisi Nasabah pada Bank Syariah (BMI, BSM, BMS) di Tinjau dari Laporan Keuangan Tahun 2008-2010 Menggunakan Metode : VaR Dan RAROC.
Yohatin, Yesica. 2009. Penggunaan

Metode CAMP Dalam

Menilai Risiko Dan Return

Saham Untuk Menentukan

Pilihan Berinvestasi Pada

Saham Jakarta Islamic Index

Periode Januari 2004-

Desember 2008 Di Bursa

Efek Indonesia.

Wikipedia. 2015. Investasi, http://id.wikipedia.org/wiki/I nvestasi, diakses pada 17 Maret 2015.

Zubir, Zalmi. 2013. Manajemaen Portofolio Penerapannya dalam Investasi Saham, Salemba Empat, Jakarta. 